\title{
Automatic Balance Mechanisms in Pay-As-You-Go Pension Systems
}

\author{
Carlos Vidal-Meliáa ${ }^{\mathrm{a}}$, María del Carmen Boado-Penas ${ }^{\mathrm{a}}$ and Ole Settergren $^{\mathrm{b}}$ \\ ${ }^{a}$ Department of Financial Economics and Actuarial Science, University of Valencia, Avenida de los \\ Naranjos s.n., Valencia 46022, Spain. \\ ${ }^{\mathrm{b}}$ Swedish Ministry of Health and Social Affairs, Socialdepartementet, Stockholm SE-103 33, Sweden.
}

The aim of this paper is twofold: to show the usefulness of automatic balance mechanisms (ABMs) and to explore the issue of introducing an ABM into the Spanish state contributory retirement pension system. With this in mind, we define the concept of the ABM and carry out an analysis of that existing in Sweden, Canada, Germany, Japan and Finland. We also present an indicator of the Spanish system's solvency which emerges from the actuarial balance sheet, and simulates the effect that certain changes in the parameters of the present system would have on solvency, showing the direction that could be taken if the mechanism were to be introduced in Spain. A comparison between the official balance sheet for the Swedish notional account system and our balance sheet for the Spanish contributory pension system is also provided.

The Geneva Papers (2009) 34, 287-317. doi:10.1057/gpp.2009.2

Keywords: actuarial analysis; actuarial balance; Spain; Sweden; political risk; solvency

\section{Introduction}

One of the main problems faced by the defined-benefit pay-as-you-go system ${ }^{1}$ (DB PAYG) is the political risk to which it is subjected, a risk that should be understood along the lines of that defined by Diamond, ${ }^{2}$ basically referring to the decisions taken by politicians tied to their traditional planning horizon (often only 4 years), which is clearly far less than that of the pay-as-you-go (PAYG) pension system. Valdés-Prieto ${ }^{3}$ points out that DB PAYG systems tend to require periodic adjustments because of demographic and economic uncertainty. Relying on discretionary legislation for these Social Security modifications creates political risk for both contributors and beneficiaries.

\footnotetext{
${ }^{1}$ The DB PAYG, the notional accounts system (NDC), has the potential to be more immune to political risk. According to Lindbeck and Persson (2003), a quasi-actuarial system with an exogenous contribution rate (i.e., a contribution-based system) will increase the financial stability of the pension system in the sense that politicians will not have made any promises concerning future pension benefits. For an international overview, see Holzmann and Palmer (2006).

${ }^{2}$ Diamond (1994).

${ }^{3}$ Valdés-Prieto (2006a).
} 
Cremer and Pestieau ${ }^{4}$ argue that economic and demographic factors play a relatively small role in the PAYG pension system's problems; political factors are far more important, and the process of reforming the pension system is mainly a political problem. The experts (economists, actuaries) ${ }^{5}$ can easily address the financial (solvency) problems caused by fluctuations in fertility rates, population ageing, increasing longevity and declining productivity growth, but social security systems are established and reformed through the political process (majority voting and lobbying). Consequently, the outcome is not likely to be socially optimal.

The most negative face of political risk is what Valdés-Prieto ${ }^{6}$ terms "populism in pensions". Populism in pensions can be defined as a form of competition between politicians in which voters are offered subsidies and benefits without the voters appreciating that it is they themselves who will pay through higher taxes, higher contributions, higher inflation or reduced economic growth. Populism manifests itself in higher spending on the pension system generated by unjustified increases in minimum pensions, the increase or extension of payments without the contributions to cover them, the awarding of disability pensions without rigour $^{7}$ and contribution subsidies. Once the elections are over, the populist politician presumably obtains his more or less ephemeral reward, but the cost to the pension system becomes structural.

Populism in pensions is aggravated if a country suffers from a weak democratic structure. Where the financial method is capitalisation, it is much more difficult for populism in pensions to appear, given that the pensions are financed in advance and there is an obligation to compile an actuarial balance sheet every year, from which derive the corrective measures to be applied when necessary.

Besley and $\mathrm{Prat}^{8}$ explain that another big problem for public (and private) pension systems is their inability to develop a credible institutional framework for contributors and pensioners in the sense that promises of payment may be reasonably respected. Boeri et al. ${ }^{9}$ note that the European PAYG pension model suffers from serious credibility problems, and the public system in Spain is no exception. Holzmann ${ }^{10}$ claims that constant tinkering with parametric reforms (changes in retirement age, changes in contribution periods leading to entitlement, increases in contribution rates (CRs)) lowers the credibility of pension systems. This credibility problem may be associated with what is known as reputational risk, which can be the result of actions that help give pension systems a bad image and give contributors a reason not to contribute or to change to other systems, should that option be available to them.

This paper reports the recent development in some countries of attempts to apply actuarial solvency analysis methodology used in insurance and capitalisation

\footnotetext{
${ }^{4}$ Cremer and Pestieau (2000).

${ }^{5}$ There exist a variety of modifications and demographic adjustment factors that are simple and transparent enough to be incorporated de facto into existing PAYG systems. See the paper by Knell (2005b) on this aspect.

${ }^{6}$ Valdés-Prieto (2006b).

7 Jimenez-Martin et al. (2006).

${ }^{8}$ Besley and Prat (2005).

${ }^{9}$ Boeri et al. (2001).

${ }^{10}$ Holzmann (2007).
} 
operations to the field of public PAYG pension system management. Further, it aims to show the usefulness of automatic balance mechanisms (ABMs) and to explore the possibility of introducing one such method into the public contributory retirement pension system in Spain. The purpose of doing this would be threefold: to adapt the system to changing socioeconomic and demographic conditions, to create a credible institutional framework to increase the likelihood that promises of pension payments will be respected and to minimise the use of the pension system as an electoral weapon.

The paper is structured as follows. The following section defines what is understood by the term "automatic balance mechanism" as applied to a pension system and includes a brief presentation of that in place in Sweden, Canada, Germany, Japan and Finland. The section "Financial solvency in the state contributory retirement pension system in Spain" charts the evolution of the actuarial balance sheet for the public contributory retirement pension system in Spain for the period 2001-2006, based on figures for the general and self-employed regimes. The solvency indicator is also analysed and the main figures are compared with those of the Swedish pension system. The section "The effect of some parametric measures on the system's solvency" shows all the parametric measures needed in order for the Spanish system to regain complete solvency, based on the situation at 31 December 2006. The section "An ABM for the case of Spain. What form could it take?" suggests how an ABM for Spain may be designed. The paper ends with the main conclusions and an appendix listing the main hypotheses applied in calculating the actuarial balance sheet along with the most important figures for the general and self-employed regimes.

\section{Automatic balance mechanism}

According to the American Academy of Actuaries, ${ }^{11}$ the first proposal for an ABM for the PAYG pension system came from actuary Robert J. Myers in 1982, while he was head of the National Commission for Social Security Reform in the United States.

The ABM is a set of predetermined measures established by law to be applied immediately as required according to the solvency or sustainability indicator. Its purpose, through successive application, is to re-establish the financial equilibrium of PAYG pension systems with the aim of making those systems viable without the repeated intervention of the legislators. In other words, they are used to depoliticise the management of the DB PAYG system by adopting measures with a long-term planning horizon, which will bring about greater intergenerational fairness and reestablish the equilibrium, sustainability or financial solvency of the system. Diamond ${ }^{12}$ states that, given the political ease of increasing benefits or reducing taxes and the political difficulty of raising taxes or cutting benefits, having future tax rate increases and future benefit decreases on the books lowers the political cost of preserving balance, since it is easier to legislate future pain than current pain.

\footnotetext{
${ }^{11}$ AAA (2002).

12 Diamond (2004).
} 
290

Börsch-Supan ${ }^{13}$ calls them rational mechanisms, as they make the process of pension system reform more rational in that, first of all, a number of rules that most people would consider reasonable are established, but are subsequently applied automatically only in specific situations in which legislation of the same measures would be accepted only with difficulty. Turner ${ }^{14}$ points out that ABMs are transparent. It is clear how adjustments will be made and who will bear what costs when an adjustment occurs.

Generalisations cannot really be made, not even for the European countries, because of the enormous differences that exist in the size of future challenges to the pension systems and the political and institutional differences that are evident from the greatly varying degrees of efficiency shown by the government departments concerned. Nevertheless, without a mechanism the necessary measures

- are not taken as quickly as they should be, which means that they need to be more extreme when they are eventually applied.

- are frequently taken without the appropriate time perspective. The turnover duration $(T D)$ of PAYG systems, that is, the time that passes from when a monetary unit enters the system as a contribution until it leaves in the form of a pension, is far longer than the electoral horizon of the politicians (often only 4 years maximum). In 2006, for example, the average $T D$ for the general and self-employed regimes in the Spanish PAYG pension system was 32.53 years, while for the Swedish system it was 31.93 years. In Canada and the United States, 75 years is used as a time perspective for the pension system, with actuarial reviews being carried out every 3 years in Canada and every year in the United States. In Japan, the time horizon is 95 years, and actuarial studies of the system are carried out every 5 years.

- are simply not adopted until the crisis in the pension system becomes impossible to ignore, although this is not usually the case in more developed countries.

The severity of the balancing measures when justified by the indicators can be of two types:

(a) The "hard" response, in which measures already included in existing legislation are immediately taken to enable the system to regain solvency through actions aimed at reducing its costs and/or increase its income.

(b) The "soft" response, in which the authority governing the system is urged to adopt measures within a time period, propose a reform, etc.

The existence of an ABM goes hand in hand with the prior calculation of a financial solvency indicator (actuarial balance sheet, actuarial report of the system's disbursements and income) or sustainability indicator (dependency rate, demographic indicators) for the pension system. Logically, the balance mechanism would be activated (triggered) when certain indicator values appear (triggering event). ${ }^{15}$

\footnotetext{
13 Börsch-Supan (2007).

14 Turner (2008).

${ }^{15}$ The German, Finnish and Japanese ABMs are permanently activated, and there is no such concept as a triggering event. They differ from the Swedish model on this point. In the Japanese case, the ABM remains activated until financial equilibrium is attained. In the case of Germany, the sustainability factor
} 
Following Penner and Steuerle, ${ }^{16}$ the ABM, despite or because of the fact that it depoliticises management by minimising political use of the pension system, has some clear advantages for politicians:

(a) It is not activated until required by the solvency indicator. If the indicator is correctly designed, it will activate when a solvency problem appears, and therefore it would be difficult to argue that it is unnecessary.

(b) Politicians do not have to legislate for reductions in the system's pensions; they just incorporate the mechanism that ensures the system's solvency into the legislation. It is probable that activation (and the subsequent reduction in pensions and/or increase in contributions) would happen some time after legislation was passed.

(c) They always have the option of suspending application of the mechanism once it has been applied for a time, thereby appearing to carry out an act of "generosity".

In the next section, we briefly describe the most relevant characteristics of five types of ABMs which are already applied to safeguard the financial sustainability of pension systems: those in Sweden, Canada, Germany, Japan and Finland. There are notable differences in the degree of sophistication and automatic activation involved, but objectives common to all of them are: to guide the system back onto the road to longterm financial stability; to automate the measures to be taken, isolating them from the political arena, avoiding their delay and a lack of time perspective; to ensure the periodic monitoring of sources of pressure on pensions; and, along with efforts to inform citizens of their pension rights, to build public confidence. There have also been calls for a mechanism of this type to be incorporated into the public social security system in the United States. ${ }^{17}$

Owing to lack of space, we have omitted other countries that have some sort of adjustment mechanism implicit in the actual definition of pension calculation (countries with notional accounts such as Italy, Latvia and Poland, or quasi-notional such as Brazil and Norway) or that have legislated for mechanisms designed mainly to deal with the expected changes in life expectancy, as in Denmark, Portugal, France and Austria.

Sweden $^{18}$

Sweden has a notional defined contribution (NDC) system and has published an actuarial income statement and balance sheet every year since 2001. It is the only country among those to be analysed whose pension system is financially sustainable in the long term in the sense that it is not necessary to make changes to the CR.

is always applied to the rate of indexation, and the ABM may possibly be deactivated, by an act of parliament, when it is judged that the social security pension scheme is sustainable under a determined contribution rate.

${ }^{16}$ Penner and Steuerle (2007).

${ }^{17}$ Palley (2000), Diamond (2004), Capretta (2006), Furman (2007), Penner and Steuerle (2007) and Turner (2008).

18 The Annual Report and an overview of the Swedish pension system as a whole can be seen on the website of the Swedish Social Insurance Agency, http://www.forsakringskassan.se/filer/publikationer/pdf/par06-e.pdf. 
According to Diamond, ${ }^{19}$ a well-structured NDC system, with a decent size buffer stock of assets, will have little probability of needing legislative intervention as long as economic growth is large enough. Even so, the Swedes have gone further by introducing an automatic balancing system.

As shown by Valdés-Prieto, ${ }^{20}$ it is only with strong restrictive conditions (constant productivity growth and a set demographic level) that automatic short-term financial viability, that is, a constant cash-flow balance between benefits and contributions, can be maintained with an NDC system. This is common sense if there is no provision for a buffer fund. Its financial sustainability has to be supported by well-known conditions based on the growth in the number of contributors and real wages, and, according to Settergren and Mikula, ${ }^{21}$ by other not so well-known conditions such as changes in mortality patterns. Valdés Prieto ${ }^{22}$ shows that, even when applying the most favourable formula, NDCs can only achieve this in a rather unrealistic steady state. Hence, NDCs also require other financial modification mechanisms - such as government guarantees and repeated recourse to legislation - to be imposed in the same way as traditional defined-benefit systems, or special measures such as ABMs.

In the intergenerational aspect, following Knell, ${ }^{23}$ NDCs are more "forward looking", while DB PAYG systems have a more "backward looking" character. "Forward looking" systems are more in line with principles of intergenerational fairness and responsibility, whereas "backward looking" systems indicate that people are obliged to shoulder the burden of changes in the size of cohorts that have been determined before they were even born, or before they were part of the electorate, the labour force and thus of the potential parent generations.

The solvency ratio indicator used emerges from the actuarial balance sheet and is expressed as

$$
\text { Solvency ratio }=\frac{\text { Assets }(\text { Financial }+ \text { Contribution })}{\text { Pension liabilities }} .
$$

The solvency ratio used in Sweden has a double purpose: to measure whether the system can fulfil its obligations to its contributors and to decide whether the ABM should be applied.

Following Settergren,${ }^{24}$ if for some reason the solvency ratio is less than 1, the ABM is triggered, as shown in Figure $1 .^{25}$ This consists basically of reducing the growth in pension liability, that is, the pensions in payment and the contributors' notional pensions capital. Thus, the "balance index" rather than the change in average salary (expressed by an "income or salary index") is used to revalue the pensions in payment and the notional account of each contributor.

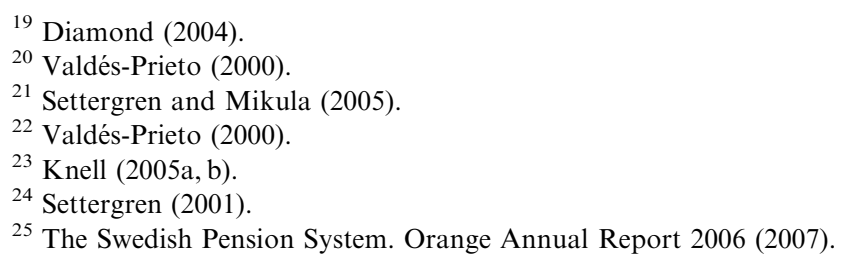




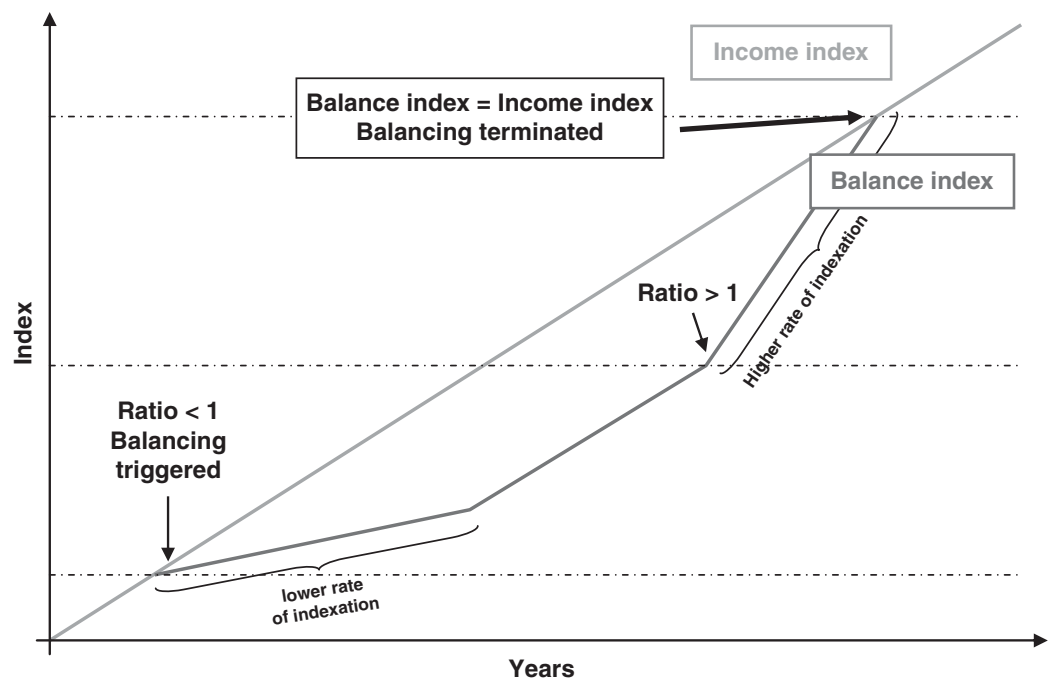

Figure 1. The automatic balance mechanism. Adapted from Orange Annual Report 2006.

The expression for calculating the "balance index" in year " $t$ ", the first year in a period when the solvency ratio is less than 1 , is

$$
B I_{t}=\frac{I_{t+i}}{I_{t+i-1}} S R_{t}
$$

where $B I_{t}$ represents the balance index in year " $t$ "; $I_{t}$ the income index in year " $t$ ", an index for the level of average income in year $t$; and $S R_{t}$ the solvency ratio in year " $t$ ".

In year " $t+i$ " the balance index is equal to

$$
B I_{t+i}=\frac{I_{t+i}}{I_{t+i-1}} S R_{t+i} B I_{t+i-1}=I_{t+i} \prod_{i=0}^{i} S R_{t+i},
$$

where $B I_{t+1}$ represents the balance index in year " $t+i$ ", $\forall_{i} ; I_{t+1}$ the income index for year " $t+i$ ", which expresses the average accumulated variation in salaries up to year " $t+i$ "; and $S R_{t+i}$ the solvency ratio in year " $t+i$ ".

If the solvency ratio is greater than 1 when the mechanism is triggered, the revaluation of the contributors' notional pension capital and pensions in payment will be greater than the change in average salary (see Figure 1). This will continue until the balance index reaches the level of the income index. This means that pensions paid during the whole balance period will reach the same value they would have had if the mechanism had not been activated.

This procedure for calculating the balance index is repeated successively until year " $s$ " in which the mechanism is deactivated, since the value of the balance index is equal to or greater than that of the income index $\left(B I_{t+s} \geqslant I_{t+s}\right)$. From year " $s$ " the 
mechanism is deactivated and the variation in pensions in payment and the notional account is equal to the variation in average salary.

The expression for the "income index" for year " $t$ " is as follows:

$$
I_{t}=\left(\frac{u_{t-1}}{u_{t-4}} \frac{C P I_{t-4}}{C P I_{t-1}}\right)^{1 / 3}\left(\frac{C P I_{t-1}}{C P I_{t-2}}\right) k I_{t-1}
$$

where $u_{t}=Y_{t} / N_{t} ; Y_{t}$ is the total pension-qualifying income without ceiling limitation, persons aged 16-64 in year " $t$ ", after deduction of the individual pension contribution; $N_{t}$ the number of persons aged 16-64 with pension-qualifying income in year " $t$ "; $C P I_{t-1}$ the consumer price index for June of year " $t$ "; and $k$ the adjustment factor for error in estimation of $u_{t-1} \cdot{ }^{26}$

The underlying philosophy of the ABM as a stabilising mechanism is spreading to various pension systems and has been especially popular with some researchers who have simulated its application in the United States, ${ }^{27}$ Japan, ${ }^{28}$ Finland, ${ }^{29}$ Germany ${ }^{30}$ and Morocco. ${ }^{31}$ It is noteworthy that during roughly the last decade, countries such as Canada, Germany, Japan and Finland have introduced different measures for stabilising the pensions to be paid, based on demographic elements or actuarial reports of contributions and disbursements.

\section{Canada}

Although the ABM in Sweden is probably the most well known to academics, a reform was also carried out in Canada in 1997 in which a sustainability clause and other changes were included in the Canada Pension Plan (CPP), converting it into a partially funded system. The CPP is a partially funded PAYG system integrated within the wideranging Canadian social security system, which combines various pillars of protection.

According to Brown, ${ }^{32}$ if any of the actuarial projections, which are carried out every 3 years with a time horizon of 75 years, concludes that the plan is not financially sustainable (if the projected CR in a stationary state for the next 75 years needs to be greater than that established by law (9.9 per cent)), a mechanism will be triggered to keep the actuarial deficit in check by increasing the CR by the amount necessary to cover 50 per cent of the deficit, while the remainder is covered by adjusting the pensions payable, that is, the amount of pensions in payment will be frozen for 3 years until a new actuarial study is carried out. However, the automatic adjustment occurs

${ }^{26}$ The rationale for the complexity of this formula is to produce a more rapid adjustment of pensions to changes in the inflation rate than would have resulted with a "pure" 3-year moving average for the development of income. The correction factor is explained by the fact that pension-qualifying income is not known until after the final tax assessment.

27 Auerbach and Lee (2006).

${ }^{28}$ Ono (2007).

${ }^{29}$ Lassila and Valkonen (2007a).

${ }^{30}$ Ferh and Habermann (2006).

31 Robalino and Bodor (2008).

${ }^{32}$ Brown (2008). 
only if the Canadian parliament cannot first decide on an adjustment, which is considered to be unlikely. The Canadian mechanism is really a semi-automatic balance mechanism.

Unlike the Swedish system, in which the weight of the adjustment falls exclusively on the amounts paid to current and future pensioners, given that the CR -18.5 per cent in Sweden - is by definition fixed, the Canadian mechanism shares the adjustment between pensions and contributions.

The legislative changes, which in 1997 led to the introduction of the mechanism described above, aimed to increase the level of funding in order to stabilise the CR in the long term, re-establish intergenerational equity and ensure the financial solvency of the CPP. Also, in order to avoid populism in pensions, it was established by law that any improvement or extension of benefits or pensions would have to be financed in advance (capitalisation system), and the decision-making process for investing in financial resources was modified with the creation of the Canada Pension Plan Investment Board.

\section{Germany}

The pension system in Germany, like that in France, relates the amount of retirement pension to the number of years contributed and the pensionable income for each of those years. This "points system" has undergone a series of reforms over the last 15 years, which have transformed it into a multi-pillar system that brings to mind the Swedish system.

As explained by Börsch-Supan, ${ }^{33}$ the formula for revaluing pensions in payment in Germany $\left(P v_{t}\right)$ includes a sustainability factor that takes into account the system's rate of dependence. This so-called "sustainability factor" proposed by the RürupKommission ${ }^{34}$ reflects the way in which the ratio between the number of contributors and the number of pensioners evolves, which is the main determinant for the long-term funding of the pension system and will reduce the amount of annual pensions if that ratio should become smaller.

$$
P v_{t}=P v_{t-1} \times \frac{A n w_{t-1}}{A n w_{t-2}} \times \underbrace{\left[\left(1-\frac{P q_{t-1}}{P q_{t-2}}\right) \times \alpha+1\right]}_{\text {Sustainability Factor }(S F)},
$$

where $P q_{t-\mathrm{i}}$ is the quotient [pensioners $(P) /($ contributors $(c)+$ unemployed $(d))$ ] in year $t-1$ and $A n w_{t-i}$ is the average net income of the whole body of contributors in the system in year $t-1$, excluding contributions to the public and private systems.

\footnotetext{
${ }^{33}$ Börsch-Supan (2006).

${ }^{34}$ Austria has also introduced a so-called "sustainability factor" (Knell et al., 2006), but it is very different from the German one. The Austrian sustainability factor (ASF) responds to deviations from forecast and refers to life expectancy developments and does not include a mechanism for automatic adjustments. It can be concluded that the ASF provides only broad guidelines on how adjustments are to be made.
} 
It is worth noting that when determining the number of pensioners, an adjustment is made according to the number that receives the minimum pension. An adjustment is also made to the number of contributors according to the contribution bases, and the number of unemployed has been added to exclude cyclical effects on the dependency ratio. Factor $\alpha$ is a parameter that redistributes the adjustment between pensioners and contributors, which means that its values will be between 0 and 1 . If $\alpha=0$, the current formula for adjusting pensions would coincide with the previous one and all the weight of the adjustment would fall on the contributors. If $\alpha=1$, all the weight of the adjustment would fall on the pensioners. According to Börsch-Supan and Wilke, ${ }^{35}$ the commission fixed the value of $\alpha$ at 0.25 , which was considered to respond to the objective of the Riester reform: to maintain the CR below 20 per cent until 2020 and below 22 per cent until 2030. Furthermore, it was stipulated that the government has to intervene if the pension level falls below 67 per cent of net earnings.

Ferh and Habermann ${ }^{36}$ have simulated the effects of the "sustainability factor", which measures changes in the dependency ratio, and of the "demographic factor", 37 which takes into account changes in life expectancy. They concluded that both reform packages redistribute resources from currently living middle-aged generations to younger and future living generations. However, the redistribution is much stronger under the "sustainability factor" than under the "demographic factor". Similarly, both reforms increase the risk exposure of currently middle-aged generations and reduce the risk for younger and future ones.

\section{Japan}

According to Sakamoto, ${ }^{38}$ a pension system financial stabiliser known as "macroeconomic indexation or modified indexation" was introduced in 2004. It is applied to both the revaluation of the contribution bases that form the regulating base (RB) for calculating the initial pension and the revaluation of pensions in payment. This financial stabiliser was proposed by the Ministry of Health, Labour and Welfare in December 2002 as an adaptation of the Swedish ABM despite their large design differences. Although the Swedish mechanism was studied in depth and appealed greatly to the Japanese authorities, according to Sakamoto ${ }^{39}$ the difficulties of applying it to the complicated Japanese defined-benefit system were clear to everyone: first, calculating the $T D$ used for calculating the Swedish solvency ratio is very difficult in a system that includes not only retirement pensions but also disability and survivor's pensions with a re-distributional flat-rate part. Second, the projected accelerated ageing process in Japan, with a rapid and long-term decrease in the working-age population, would continually overestimate the " $T D$ ".

\footnotetext{
${ }^{35}$ Börsch-Supan and Wilke (2006).

${ }^{36}$ Sakamoto (2005).

${ }^{37}$ The former conservative government in Germany introduced a so-called "demographic factor", which was supposed to reduce future benefits in accordance with the increase in future life expectancy. This reform was suspended soon after the change of government in 1998.

${ }^{38}$ Sakamoto (2005).

${ }^{39}$ Ibid.
} 
The aim of "macroeconomic indexation" in Japan is to reduce spending on pensions to a particular level for a particular time from 2005 and to adapt spending to the CR, which will be fixed in 2017. The Japanese financial stabiliser takes into account both improvements in life expectancy and population decreases. The formula applied to revalue the contribution bases until retirement to form the $\mathrm{RB}$ is

$$
\operatorname{Max}\{\beta+\operatorname{Min}\{\delta, 0\}-0.3 \text { per cent, } 0 \text { percent }\}
$$

with $\beta$ being the net growth in salaries and $\delta$ the growth rate of the contributing population. It is forecast that contributing population will decrease by 0.6 per cent accumulatively per year for the period 2005-2025.

For the indexation of pensions in payment:

$$
\operatorname{Max}\{R P I+\operatorname{Min}\{\delta, 0\}-0.3 \text { percent, } 0 \text { percent }\}
$$

where $R P I$ is the retail price index. In both formulas 0.3 per cent is defined as the adjustment rate that compensates for the increase in costs deriving from the increase in longevity. According to Sakamoto, ${ }^{40}$ this is a fixed rate that compensates for the average annual increase in life expectancy for individuals aged 65 in the period 2000-2025.

As Sakamoto ${ }^{41}$ points out, the "modified indexation" gradually reduces the level of benefits until financial equilibrium is attained. After financial equilibrium is attained, the indexation is to revert to normal indexation. In this sense, the modified indexation is a transitional framework.

Unlike Sweden, this case also contemplates an increase in the CR - it will rise from 14.288 per cent in 2005 to 18.30 per cent in 2017 - which means that if life expectancy increases, the expected decrease in the amount of initial pensions brought about by this increase will not be quite so large because of the greater amount of contributions. The replacement rate (RR) specifically defined for monitoring the benefit level is forecast to decrease from 59.3 per cent in 2004 to 50.2 per cent in 2023 .

According to Sakamoto, ${ }^{42}$ every 5 years a new actuarial report will be issued, which will be able to modify the adjustment factor according to the number of contributors and the evolution of pensioners' life expectancy. This report takes into account the evolution of these variables for a time horizon of 95 years with the aim of achieving financial equilibrium.

The application of the financial mechanism is suspended if the actuarial valuation projects that financial equilibrium will be attained for the next 95 years under normal indexation.

\footnotetext{
${ }^{40}$ Ibid.

${ }^{41}$ Sakamoto (2008).

${ }^{42}$ Sakamoto (2005).
} 


\section{Finland}

Following Hietaniemi and Ritola ${ }^{43}$ and Lassila and Valkonen, ${ }^{44}$ the most important changes in the extensive pension reform of 2005 were the consideration of earnings during the whole of working life (WL) as pensionable earnings, the introduction of a flexible retirement age of between 63 and 68 for the old-age pension, the raising of the age limits for pre-retirement pensions, the total abolition of unemployment and individual early retirement pensions and also the taking into account of increased longevity in the pension amount (life expectancy coefficient). In addition, the rules governing calculation in the different pension acts were further harmonised.

The "life expectancy coefficient" automatically adjusts the amount of pensions in payment as longevity increases (or decreases). In the formula, to be enforced in 2010, the amount of new pensions will depend on life expectancy as of 2010 compared to that of 2009. Its equation, which will be calculated annually for the 62-year-old cohort, is

$$
E V C_{N}=\frac{E V_{2009}^{62}}{E V_{N}^{62}},
$$

where $E V C_{N}$ is the life expectancy coefficient in $N(>2009), E V_{2009}^{62}$ the life expectancy of those who reach age 62 in 2009 and $E V_{N}^{62}$ the life expectancy of those who reach age 62 in $N(>2009)$.

The "life expectancy coefficient" automatically links the pension amount for each cohort of new retirees to changes in longevity. The coefficient will have a value less than 1 if life expectancy grows after 2010. This coefficient gives the contributor the choice of maintaining the amount of pension initially awarded by prolonging his WL or accepting a smaller pension to compensate for the increase in longevity (the pension is multiplied by the value of the coefficient).

The introduction of the "life expectancy coefficient" (see Lindell ${ }^{45}$ ) was preceded by a debate on the best way to compensate for the increase in longevity, either by establishing higher retirement ages or by offering the contributor the choice of a smaller pension than that initially expected owing to the increase in longevity, but keeping the same retirement age, or a pension for the same amount as that expected but with a later retirement age.

Lassila and Valkonen ${ }^{46}$ have simulated the effects of the planned mechanism and concluded that it will lower the amount of future pensions, with those most affected being current generations of middle-aged people, and that the Finnish system will change its nature, tending from defined-benefit towards definedcontribution.

\footnotetext{
${ }^{43}$ Hietaniemi and Ritola (2007).

${ }^{44}$ Lassila and Valkonen (2007b).

${ }^{45}$ Lindell (2004).

${ }^{46}$ Lassila and Valkonen (2007a).
} 


\section{Financial solvency in the state contributory retirement pension system in Spain}

International organisations (European Union, World Bank and OECD) and prominent researchers ${ }^{47}$ have all recommended an in-depth modification of the Spanish state pension system. All the studies analysed have highlighted three issues:

- The current configuration of the pension system is not the best possible.

- Financial solvency cannot be achieved with the current system. Additional reforms to ensure the financial sustainability of the pension system in the long term will soon be necessary.

- The current system is not actuarially fair. The way the social security system in Spain is divided into a series of special systems leads to differences in the way individuals of the same generation are treated.

Using the methodology of Boado-Penas et al. ${ }^{48}$ who, as far as they can, follow the philosophy used to compile the Swedish balance sheet, an actuarial balance sheet ${ }^{49}$ is compiled for the period 2001-2006 for the general and self-employed regimes. At 31 December 2006, these accounted for 92.4 per cent of contributors and 68.3 per cent of retirement pensioners.

The evolution of this actuarial balance sheet is shown in Table 1 .

The "contribution asset" $(C A)$ is the highest level of liabilities that can be financed in the long term by the current $\mathrm{CR}$ and number of contributors (income from contributions stable in time) without requiring extraordinary contributions from the sponsor. This is the main methodological innovation that enables the actuarial balance sheet of the PAYG system to be compiled. The value of the $C A$ is the product of the $T D$ and the value of the contributions made in that period. The $T D$ is the time that is expected to pass from when a monetary unit enters the system as a contribution until it leaves in the form of a pension. It is also the sum of the weighted pay-in and pay-out durations of one monetary unit in the system for the year's contributions, and is based on population data obtained from a cross-section, not from a projection. ${ }^{50}$ The value of the $C A$ has decreased notably over these 6 years owing to the fact that the $T D$, as shown in Figure 2, has decreased because of the effect of the ageing of the contributors' group and because the contributions collected have grown at a rate lower than the increase in GDP. The real average contribution per contributor has decreased.

The item "Losses for the Period" represents the difference between the increase in the value of actuarial liabilities and assets for the period. If the increase in assets were

\footnotetext{
${ }^{47}$ A summary of the most relevant research on Spain can be found in the paper by Vidal-Meliá and Domínguez-Fabián (2006).

48 Boado-Penas et al. (2008).

${ }^{49}$ It is worth noting that the actuarial balance sheet is not the only tool to disclose the financial status of pension systems. As stated before, in Canada, the United States and Japan (among other countries), actuarial studies (projections) with a long-term horizon (75-95 years) are carried out every 3, 1 and 5 years, respectively. In fact, long-term projections of the system's possible future evolution are also included in the annual report of the Swedish pension system. However, this information is not used in the preparation of the actuarial balance sheet or to make annual decisions or adjustments that may affect contributors and pensioners.

${ }^{50}$ See Appendix for more details.
} 
Table 1 Balance sheet at 31 December of each year for the Spanish pension system for the period 2001-2006 as per cent of GDP: general and self-employed regimes

\begin{tabular}{|c|c|c|c|c|c|c|}
\hline Year & 2006 & 2005 & 2004 & 2003 & 2002 & 2001 \\
\hline \multicolumn{7}{|l|}{ Assets } \\
\hline Financial asset & 3.7 & 3.0 & 2.3 & 1.5 & 0.9 & 0.4 \\
\hline Contribution asset & 182.8 & 180.1 & 180.3 & 185.0 & 186.7 & 193.4 \\
\hline Accumulated deficit & 72.1 & 74.8 & 65.2 & 61.8 & 52.2 & 56.0 \\
\hline "Losses for the period" & 3.8 & 3.0 & 15.5 & 8.2 & 14.1 & - \\
\hline Total assets & 262.5 & 260.9 & 263.3 & 256.5 & 253.8 & 249.7 \\
\hline \multicolumn{7}{|l|}{ Liabilities } \\
\hline Liability to pensioners & 48.3 & 48.5 & 48.4 & 48.6 & 49.5 & 48.3 \\
\hline Liability to contributors & 214.2 & 212.4 & 214.9 & 207.9 & 204.3 & 201.4 \\
\hline Total liabilities & 262.5 & 260.9 & 263.3 & 256.5 & 253.8 & 249.7 \\
\hline \multicolumn{7}{|l|}{ Funding, solvency and liquidity indicators } \\
\hline $\begin{array}{l}\text { Solvency ratio ((financial + contribution) } \\
\times \text { assets/liabilities) }\end{array}$ & 0.711 & 0.702 & 0.694 & 0.727 & 0.739 & 0.776 \\
\hline Growth in assets $(\%)$ & 9.83 & 8.04 & 5.11 & 6.77 & 3.67 & \\
\hline Growth in liabilities $(\%)$ & 8.49 & 6.80 & 10.19 & 8.46 & 8.88 & \\
\hline Degree of funding (\%) (financial asset/liabilities) & 1.40 & 1.15 & 0.26 & 0.25 & 0.21 & 0.23 \\
\hline (Liabilities to contributors/liabilities) $(\%)$ & 81.6 & 81.4 & 81.6 & 81.1 & 80.5 & 80.7 \\
\hline Ratio contributions/benefits & 1.369 & 1.343 & 1.350 & 1.381 & 1.374 & 1.379 \\
\hline
\end{tabular}

Source: Own.
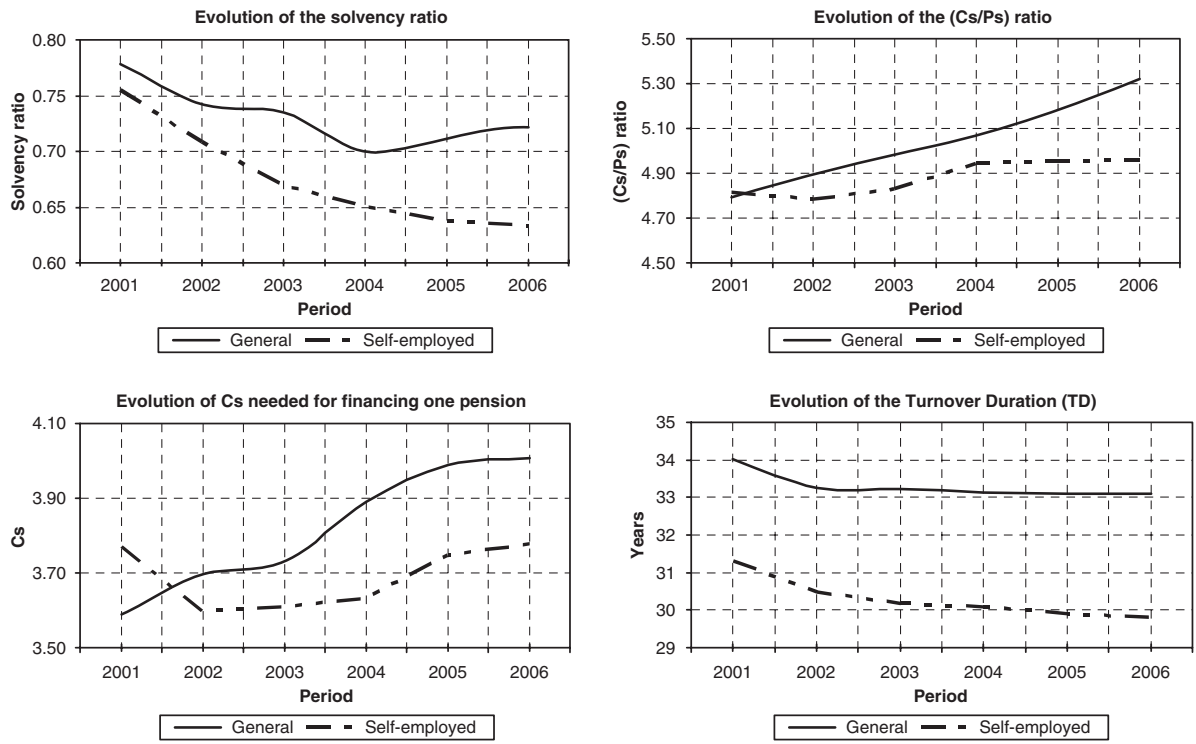

Figure 2. Evolution of the solvency ratio, the contributor-pensioner ratio, number of contributors $(C \mathrm{~s})$ necessary to finance a pension and TD for the period 2001-2006. General and self-employed regimes.

greater than that of the liabilities, there would be "actuarial profits". The condition allowing the solvency ratio to improve is not for there to be "profits"; the ratio can improve (increase its value) if the variation in the relative value of the liabilities is 
lower than the variation in the relative value of the assets, which is what happened in 2005 and 2006. The accumulation of losses determines the value of the capital deficit, which is shown in the balance sheet.

The "Liability to Pensioners" is the present value of all pensions in payment, and its amount remains stable in terms of share of GDP. The "Liability to Contributors" is the difference between the present value of the insurers'/state's obligations to these people and the same contributors' projected contributions. It is the liability for contributions made and to be made by existing contributors. Its value represents more than 80 per cent of the total commitments acquired by the system, and the amount grows more rapidly than the GDP for the period.

The degree of funding is the relation between the financial assets and the liabilities taken on by the system. If the ratio were 100 per cent, the system would be completely funded; in other words, all its obligations would be financed in advance.

The annual contributions/pensions ratio is the system's liquidity indicator. It is the ratio between income from contributions and spending on contributory retirement pensions. It includes the effect of considering allocations for minimum pensions as contributions. The ratio is greater than 1 , which indicates that there is a cash surplus, and consequently the financial assets entry on the balance sheet increases on a year-to-year basis.

The solvency ratio shown on the actuarial balance sheet is the indicator used to measure the solvency or financial sustainability of the contributory retirement pension system. It is the quotient between the assets and liabilities of the system.

In general terms it can be said that a PAYG pension system is reasonably solvent and that therefore at the date of the balance sheet the participants should have a realistic expectation of receiving the benefits that have been promised, without the sponsor of the system (the state) having to make periodic contributions - as long as: (Financial and Real Assets + Contribution Asset) $\geqslant($ Liability to Pensioners + Liability to Contributors). This condition implies that the accumulated deficit must be nil or negative (solvency ratio $\geqslant 1$ ). If the accumulated deficit is positive, the pension system is not fully solvent (partially solvent) (solvency ratio $<1$ ). This means that at some point in the future, the sponsor will be forced to allocate extraordinary funds to cover the deficit, or that the promises made to some of the participants will be at least partially broken. Our concept of sustainability relates to solvency, the ability of the pension system to service its commitments without allocating extraordinary funds to cover the actuarial deficit. ${ }^{51}$ Likewise, solvency and financial stability are very close concepts. ${ }^{52}$

51 This definition does not mean that in a particular situation, the contribution rate will not have to be increased in order to achieve equilibrium in the balance sheet. This is logical since the concept of solvency derives from the field of insurance and defined benefit capitalisation systems, and the measures that are usually applied when actuarial deficits appear on numerous occasions include an increase in the contribution rate. This is one of the main differences between sustainability and solvency. According to Knell et al. (2006), the term "sustainability" has many definitions, although it almost always refers to the fiscal policies of a government, the public sector or the pension system. One of the most widely accepted definitions in the area of pensions is that of "a position where there is no need to increase the pension contribution rate in the future".

${ }^{52}$ For Lindbeck and Persson (2003), a pension system is regarded as financially stable if the capital value of expected pension payments is equal to the capital value of the system's revenues from contributions. This should hold in the aggregate. For actuarial fairness, it should also hold for the individual. 
As can be seen, and unlike what is generally perceived on the basis of considering the liquidity indicator (cash surplus) and the increase in contributors, the system is partially insolvent and the situation has worsened over the last 6 years. As shown in Table A1, the accumulated increase in numbers of contributors for the period 20012006 is 20.38 per cent, which exceeds the increase in numbers of pensioners, which was only 9.95 per cent for the same period, and therefore the contributor/pensioner ratio has improved, rising from 4.80 to 5.25 . However, the most relevant ratio is that which shows the number of contributors needed to finance a retirement pension, and this has increased from 3.48 to 3.84 . Figure 2 shows these two ratios separately for the two regimes under consideration. This situation has come about owing to the fact that there was no increase in salaries in real terms during the period 2001-2006. This can be seen from the average annual contribution, which decreased from 3,196 euros/year in 2001 to 3,178 euros/year in 2006 , together with the real increase in the annual average pension for the same period, which rose from 11,122 euros/year in 2001 to 12,196 euros/year in 2006 (Table A1).

In 2001 the solvency ratio reached a value of 0.776 , that is, 22.4 per cent of the commitments taken on lacked financing under current legislation; 5 years later, in 2006, the ratio is 0.711 , which means that the degree of long-term financing of liabilities has descended by 6.5 percentage units, that is, 28.9 per cent of liabilities are not supported by a financial asset or contributions. Figure 2 shows the evolution of the separated solvency ratio. It can be seen that in the general regime there has been a slight improvement over the last 2 years, whereas solvency in the self-employed regime has worsened year after year.

All in all, and despite the fact that in 2006 the solvency of the system as a whole improved slightly with respect to 2005 , there exists a capital deficit of 28.9 per cent of liabilities. Contrary to some official declarations of optimism as to the financial health of the contributory pension system, the actuarial balance sheet shows a very compromised position of solvency and a notable actuarial imbalance, which calls for immediate reforms.

If we compare Table 2 (Sweden) and Table 1 (Spain), ignoring the general opinion that comparisons are always difficult, we can immediately see the difference between a solvent system (Sweden) with financial backing for all its liabilities and an insolvent one (Spain) with financing for only 71.1 per cent of its liabilities in 2006. It is also easy to see the difference between a balanced system (Sweden) in which the variation rates of assets and liabilities are similar because new affiliates do not bring an additional deficit with them, and an unbalanced system (Spain) in which the variation rate for liabilities is greater (much greater for some of the period) than the rate for assets because new affiliates imply an additional deficit for the pension system (more and more contributors are needed to finance a pension), and pensions in payment (especially minimum pensions) grow at a rate above the real rate of inflation.

What measures would need to be applied if the public system were a private capitalisation pension plan covered by Spanish legislation? This situation of insolvency or accumulated deficit would require the immediate application of correcting measures. Under current Spanish legislation, ${ }^{53}$ like that in the rest of the European

${ }^{53}$ ORDER EHA/407/2008. 
Table 2 Balance sheet of the Swedish pension system at 31 December of each year for the period 2001-2006 as per cent of GDP

\begin{tabular}{|c|c|c|c|c|c|c|}
\hline Year & 2006 & 2005 & 2004 & 2003 & 2002 & 2001 \\
\hline \multicolumn{7}{|l|}{ Assets } \\
\hline Financial asset & 30.3 & 28.8 & 25.2 & 23.5 & 20.6 & 24.7 \\
\hline Contribution asset & 209.9 & 214.2 & 218.6 & 222.2 & 223.2 & 222.2 \\
\hline Total assets & 240.2 & 243.0 & 243.8 & 245.7 & 243.7 & 246.9 \\
\hline \multicolumn{7}{|l|}{ Liabilities } \\
\hline Liability to contributors & 167.8 & 172.7 & 174.9 & 175.4 & 175.3 & 172.3 \\
\hline Liability to pensioners & 68.9 & 69.2 & 68.5 & 67.9 & 66.3 & 65.1 \\
\hline Accumulated surplus & 1.0 & 0.3 & 2.3 & 2.1 & 9.2 & 9.5 \\
\hline Change in net worth & 2.5 & 0.7 & -1.9 & 0.3 & -7.0 & \\
\hline Total liabilities & 240.2 & 243.0 & 243.8 & 245.7 & 243.7 & 246.9 \\
\hline \multicolumn{7}{|l|}{ Funding and solvency indicators } \\
\hline Solvency ratio & 1.015 & 1.004 & 1.001 & 1.010 & 1.009 & 1.040 \\
\hline Variation of assets $(\%)$ & 4.82 & 3.79 & 3.49 & 4.53 & 2.30 & \\
\hline Variation of liabilities $(\%)$ & 3.74 & 3.48 & 4.34 & 4.46 & 5.46 & \\
\hline Degree of funding $(\%)$ & 12.80 & 11.90 & 10.35 & 9.64 & 8.51 & 10.40 \\
\hline (Liabilities to contributors/liabilities) $(\%)$ & 70.9 & 71.4 & 71.8 & 72.1 & 72.6 & 72.6 \\
\hline
\end{tabular}

Source: Based on Boado-Penas et al. (2008).

Union, any pension plan deficit should be eliminated by extraordinary contributions from the sponsor (which in the public system is the state) within a period of time no greater than 5 years (or 10 years in exceptional cases). It is also established that when the deficit is greater than 10 per cent (in the public system it is 28.9 per cent, as we have just seen), a review should be carried out of the assumptions used in the technical basis (equivalent to the parameters determining payments in the public system) unless there are reasons for believing that the deficit has arisen for a extraordinary reason. Finally, the hypotheses used should be changed when the pension plan's deficit, although below 10 per cent, still constitutes a substantial percentage and is present over the course of various tax years (over the last 6 years the public system has shown losses and in some cases very high losses).

The absence of an (official) actuarial balance sheet in the case of Spain produces a "mirage effect" by hiding the presence of a capital deficit coexisting with a large cash surplus. It also diminishes the importance of future cash deficits and above all defers the taking of effective measures to restore the system's solvency and eliminate the "losses" or increases in the accumulated deficit, which grows each year that passes without reform.

Restoring solvency to the Spanish system would require the immediate application of a set of gradual but far-reaching measures to reduce the speed at which the liabilities are growing, this being a key aspect for leading the system back to solvency in the long term. The most immediate aim of public policy should be to stop the pension system accumulating "losses" year after year, in other words to regain actuarial equilibrium 
304

(by reducing the contributor's expected internal rate of return (IRR) ${ }^{54}$ and not increase insolvency and consequently the size of the problem.

The adoption of measures is more urgent than might appear owing to the foreseeable ageing of the population (if demographic projections are correct, the age of the median Spanish voter will increase by 13 years, rising from 44 in 2000 to 57 in 2050), given that reform of the pension system will become more and more difficult to undertake without the majority support of the electorate, whose interests will be represented by individuals who consider that it will (apparently) cost less and less to finance the current system from which more and more is obtained, a product of the structural actuarial imbalance.

\section{The effect of some parametric measures on the system's solvency}

As already mentioned, regaining solvency in the case of Spain would demand the application of a combination of parametric measures. These could include an increase in the CR, an increase in the number of years to be included in the RB, an increase in retirement age and/or a life expectancy adjustment mechanism as in Finland and Sweden, a decrease in the RR, the indexation of pensions in payment at a rate below inflation or a combination of the above. Hence, for example, for the Spanish system to achieve solvency through an increase in the CR, this rate would have to go up by 22.66 per cent for the general regime (rising from 18.92 per cent, the CR for the retirement contingency in 2006, to 23.21 per cent) and by 35.74 per cent for the self-employed regime (rising from 17.83 per cent, the $\mathrm{CR}$ for the retirement contingency in 2006, to 24.20 per cent) compared with current values.

All the measures have a common denominator: they reduce the extremely high IRR expected by contributors. Table 3 shows the initial impact that the adopted measure would have on different entries on the balance sheet. It should be taken into account that the total effect of these measures on the balance sheet would not be immediate and that the balance sheet would adapt to the new situation as new facts were verified and could be quantified. According to our calculations, it is obvious that various measures could be taken to achieve solvency in 2006, such as raising the CR by more than five percentage units, reducing the RR by up to 75 per cent, increasing the retirement age to 71, reducing the value of pensions in payment by over 2 per cent in real terms annually or a more gentle combination of the above. Obviously some or most measures taken in isolation are unfeasible.

Table 4 shows the effect of different combinations of parametric solutions taken two at a time. The combinations that achieve the best level of solvency, values between 1 and 1.1, are those shaded dark grey in the table. Without shading are those situations in which there is excess solvency, which would cause undue harm to current contributors by reaching levels of over-solvency, turning the PAYG system into a different system with a very high degree of funding. Those situations in which

\footnotetext{
${ }^{54}$ On this aspect, a key factor in the Spanish system's insolvency, see the papers by Vidal-Meliá et al. (2006) and Boado-Penas et al. (2007). The expected IRR for an average contributor varies between 4 and 5 per cent in real terms.
} 
Table 3 Immediate effect of parametric reforms on the main entries on the balance sheet at the moment of change

\begin{tabular}{llll}
\hline Measures & Contribution asset & Liabilities \\
\cline { 3 - 4 } & & $\begin{array}{l}\text { Liability to } \\
\text { pensioners }\end{array}$ & Liability to contributors \\
Change in CR & $\begin{array}{l}\text { Changes } \\
\text { proportionally } \\
\text { No change }\end{array}$ & No change & $\begin{array}{l}\text { Change in future contributions } \\
\text { (net liability change) } \\
\text { Change in future benefits } \\
\text { (net liability change) }\end{array}$ \\
$\begin{array}{lll}\text { Change in RR } \\
\text { Change in pensions } \\
\text { in payment, } \lambda\end{array}$ & No change & No change & $\begin{array}{l}\text { Change in future benefits } \\
\text { (net liability change) }\end{array}$ \\
Change in retirement & No change & $\begin{array}{l}\text { Net liability } \\
\text { change } \\
\text { (net liability change) }\end{array}$ & $\begin{array}{l}\text { No change } \\
\text { Change in future contributions } \\
\text { and benefits (net liability change) }\end{array}$ \\
\hline
\end{tabular}

Source: Own.

Table 4 (In)Solvency ratio (SR) after changes in parametric measures (general and self-employed regimes)

\begin{tabular}{|c|c|c|c|c|c|c|c|c|c|c|c|c|c|c|}
\hline \multirow{2}{*}{\multicolumn{2}{|c|}{ Items }} & \multicolumn{3}{|c|}{ RB } & \multicolumn{3}{|c|}{ RR } & \multicolumn{3}{|c|}{$\lambda$ per cent } & \multicolumn{4}{|c|}{ Ar } \\
\hline & & 15 & 25 & WL & 100 & 90 & 80 & 0 & -0.5 & -1 & $\mathbf{N}$ & 66 & 68 & 70 \\
\hline \multirow{4}{*}{ CR } & $=$ & 0.711 & 0.730 & 0.751 & 0.711 & 0.799 & 0.918 & 0.711 & 0.768 & 0.831 & 0.711 & 0.713 & 0.827 & 0.988 \\
\hline & +1.5 & $\overline{0.798}$ & 0.822 & 0.846 & $\overline{0.798}$ & 0.903 & 1.045 & $\overline{0.798}$ & 0.866 & 0.941 & $\overline{0.798}$ & 0.805 & 0.939 & 1.133 \\
\hline & +3 & 0.894 & 0.921 & 0.950 & 0.894 & 1.017 & 1.186 & 0.894 & 0.974 & 1.062 & 0.894 & 0.905 & 1.064 & 1.299 \\
\hline & +4.5 & 0.999 & 1.038 & 1.072 & 0.999 & 1.143 & 1.345 & 0.999 & 1.092 & 1.196 & 0.999 & 1.014 & 1.203 & 1.489 \\
\hline \multirow{3}{*}{ RB } & 15 & & & & $\underline{0.711}$ & 0.799 & 0.918 & $\underline{0.711}$ & 0.768 & 0.831 & 0.711 & 0.713 & 0.827 & 0.988 \\
\hline & 25 & & & & 0.730 & 0.822 & 0.946 & 0.730 & 0.790 & 0.855 & 0.730 & 0.721 & 0.817 & 0.950 \\
\hline & WL & & & & 0.751 & 0.847 & 0.975 & 0.751 & 0.814 & 0.882 & 0.751 & 0.744 & 0.843 & 0.978 \\
\hline \multirow{3}{*}{$\mathbf{R R}$} & 100 & & & & & & & $\underline{\underline{0.711}}$ & 0.768 & 0.831 & $\underline{0.711}$ & 0.713 & 0.827 & 0.988 \\
\hline & 90 & & & & & & & & 0.867 & 0.941 & 0.799 & 0.828 & 0.972 & 1.179 \\
\hline & 80 & & & & & & & & 1.001 & 1.092 & 0.918 & 0.984 & 1.175 & 1.457 \\
\hline \multirow{3}{*}{$\begin{array}{c}\lambda \\
\text { per } \\
\text { cent }\end{array}$} & $\mathbf{0}$ & & & & & & & & & & $\underline{0.711}$ & 0.713 & 0.827 & 0.988 \\
\hline & -0.5 & & & & & & & & & & 0.768 & 0.769 & 0.889 & 1.062 \\
\hline & -1 & & & & & & & & & & 0.831 & 0.829 & 0.957 & 1.142 \\
\hline
\end{tabular}

Year 2006. Source: Own.

solvency, without being total, reaches acceptable levels, between 0.9 and 0.99 , are shaded lighter grey. Finally, the lightest grey shading shows those combinations providing solvency values lower than 0.9 , which, although they do improve the level of solvency, cannot be considered sufficient.

If three parametric measures together are considered, including as a fixed measure the extension of the RB to cover the whole WL, the solvency ratio would automatically take on reasonable values, at least 0.9 , with a combination of an increase in the CR of more than two percentage units, a reduction in the RR down to approximately 85 per cent, a reduction in pensions in payment of over 0.5 per cent accumulative per year or the establishment of an effective retirement age of 67 . 
Another combination could be a reduction in pensions of 0.5 per cent and an effective retirement age of 67 , or even a retirement age of 67 plus a reduction in the RR down to perhaps 90 per cent, both of these still combined with an increase in the RB to cover the entire WL.

There are notable differences if solvency is considered separately for each of the regimes, as was shown in Figure 2. The solvency situation is different in the general and self-employed regimes because of, for example, the different contributorpensioner ratios and their respective contribution profiles. In the self-employed regime (see Figure 3), contributors "optimise" their contributions to maximise their pension entitlement, and this has the effect of causing a greater actuarial imbalance. Most contributors in the self-employed regime pay minimum contributions for the years that are not taken into account to calculate the RB for retirement pension, then increase their contributions considerably during their last 15 working years, which are those taken into account for calculating the RB. This bad, or rational, behaviour is much more common for men than it is for women, and is later reflected in the amount of pension obtained, which is much higher for men than women.

There are a great many combinations enabling solvency to be achieved. The best way would be to select a combination of measures, then apply them gradually, sharing the adjustment load between contributors and pensioners, and thereby gradually improve the solvency ratio. From the political point of view, it is clear that adopting these measures in a situation of cash surplus and government euphoria would be very difficult unless a pact was made with the consensus of at least the two main political
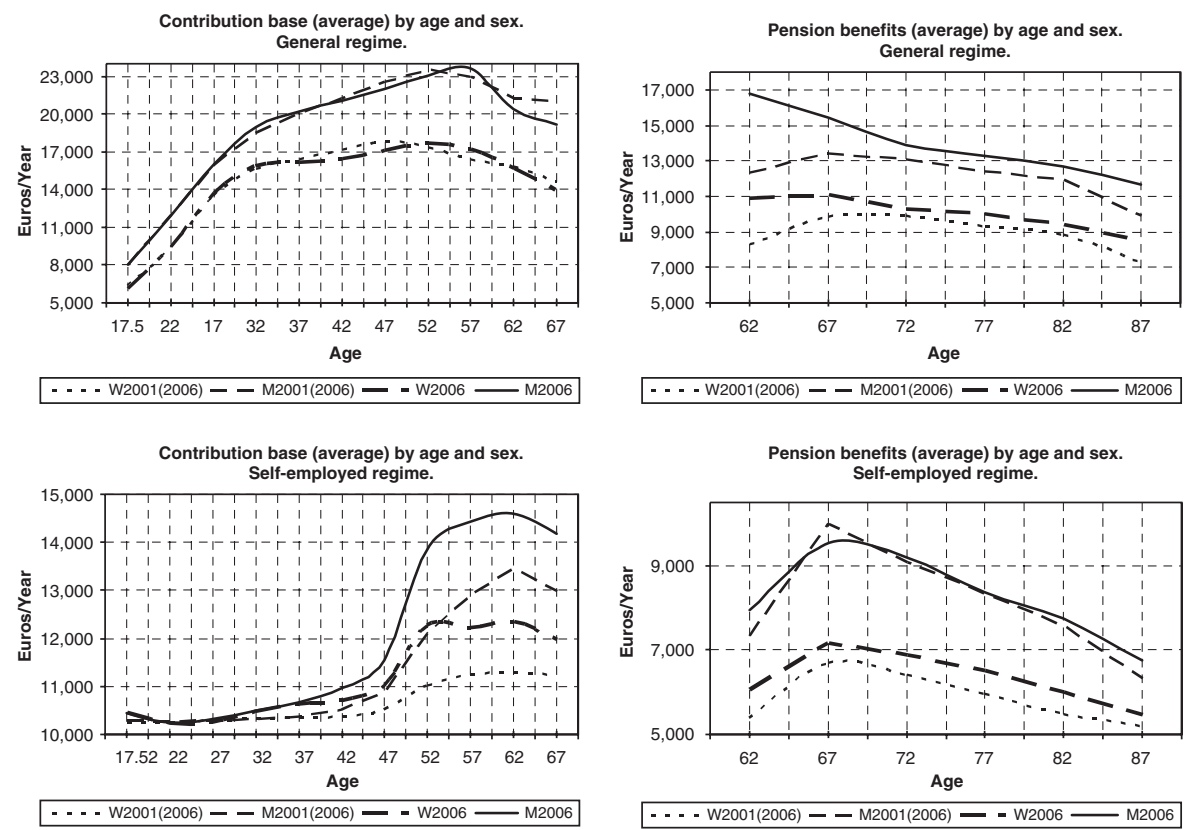

Figure 3. Average profiles of contribution bases and pensions by age for men and women. General and self-employed regimes (2001 and 2006). 2006 euros. 
parties. Another likely requirement for such political decisions - sufficient popular acceptance of them - would be regular, preferably annual, high-quality and trustworthy official presentations of the pension system's estimated solvency.

It can be concluded that the actuarial structure for the Spanish contributory pension system: 15 (the number of years to be included in the RB), 35 (years of contributions), 65 (age of retirement) and 100 (theoretical RR) is unsustainable, insolvent, unbalanced and unfair, and it should be substituted by more sustainable, realistic and fair figures: 40-45 (years of contributions and full WL), 65-70 (retirement age) and 80-85 (theoretical RR), in order to balance the system by reducing the expected IRR for contributors.

\section{An ABM for the case of Spain. What form could it take?}

Without renouncing the need for a more far-reaching reform, for example, the introduction of a notional accounts system across all regimes of the Spanish contributory system as proposed by Vidal-Meliá and Domínguez-Fabián, ${ }^{55}$ there appears to be an urgent need for at least the introduction of an ABM into the Spanish contributory pension system.

There is not a very wide choice as to the design of the mechanism in the case of Spain, given that the degree of insolvency is high and there also exists a clear structural actuarial imbalance. The intensity of the mechanism should be of the hard response type, in which pensions are reduced and contributions increased simultaneously, along with an obligation to carry out structural (notional) reform within a certain period of time (5 years).

The hardest response that can be given is to change or redesign the system completely, but of course then it would no longer be an ABM since it would require a whole political negotiation process that could take a great deal of time. Nonetheless, owing to the fact that the solvency deficit is hidden and, in addition, exists side by side with a cash surplus that at present enables pensions to be paid without any cash-flow problems, it would seem to be a better idea (from the point of view of acceptance by the general public) to agree some automatic measures to gradually push the system back onto the road to solvency and start a traditional reform process aimed at redesigning the system along the lines of notional philosophy.

The design outlines for the mechanism have been described in the previous section:

(1) The number of years used to calculate the RB should gradually be extended to cover the whole WL (one additional year for each year that passes) regardless of the value of the solvency indicator. According to Lindbeck and Persson, ${ }^{56}$ this measure raises the degree of intergenerational and actuarial fairness, minimises potential work disincentives and the preferred treatment of shorter working periods and eradicates the (bad) effect of steeper earnings profiles. According to

\footnotetext{
${ }^{55}$ Vidal-Meliá and Domínguez-Fabián (2006).

${ }^{56}$ Lindbeck and Persson (2003).
} 
the information provided by Whitehouse, ${ }^{57}$ most developed countries either take into account all the years contributed when calculating pensions or are in the process of reaching the point where they will: Austria, Belgium, Canada, Finland, Germany, Japan, Korea, Italy, Luxemburg, Holland, Portugal, Sweden, Switzerland, the United Kingdom, Latvia, Lithuania, Poland, Slovakia and Turkey. ${ }^{58}$

(2) As established by Whitehouse ${ }^{59}$ and Queisser and Whitehouse, ${ }^{60}$ it is hard to deny that the RR promised by the Spanish contributory retirement pension system is very high, especially when compared with the contribution effort and with the main countries of the OECD. The mechanism should include a gradual reduction in the RR as an element helping to lead to the system's solvency. This reduction could be between 0.25 and 0.75 per cent for each year in which the solvency indicator remains below the reference value, although a minimum RR should be legislated in order to guarantee an adequate old-age benefit.

(3) As seen in the previous section, delaying the effective retirement age has a great effect on the system's solvency. The balance mechanism could take retirement age into account from a double perspective:

- Gradual automatic increases in the ordinary age of retirement (e.g., between 2 and 3 months a year for each year that the solvency indicator was below its reference indicator). This measure would not need to be used in the mechanism if in the end the pension system were reformed to become an NDC, because the additional contributions made would revert directly to the contributor in the form of greater pension rights.

- Additional reductions in the RR at normal retirement age in line with changes in longevity (life expectancy), which would preferably be independent of the system's situation of solvency. This mechanism would be similar to notional account philosophy and like the mechanism applied in Finland in the shape of a "life expectancy coefficient". In Spain, life expectancy at age 65 for the population as a whole over a period of 18 years (1980-1998) ${ }^{61}$ rose from 16.52 years to 18.25 . However, the RR has remained unchanged for age 65 . If a life expectancy coefficient similar to that in Finland, Portugal or Norway were applied, the RR would be 90.52 per cent instead of the current 100 per cent, because of the effect of greater longevity. With this measure alone solvency in 2006 would rise from 0.711 to 0.794 . Another alternative, as suggested by Diamond and Orszag ${ }^{62}$ and applied in Germany, ${ }^{63}$ would be to distribute the gains in longevity between pensioners and contributors with the aim of reducing the adjustment to be made to the RR.

\footnotetext{
${ }^{57}$ Whitehouse (2007).

${ }^{58}$ This point is really more part of a parametric reform of the scheme aiming towards financial stability and fairness. In the Spanish case it is necessary.

${ }^{59}$ Whitehouse (2006).

${ }^{60}$ Queisser and Whitehouse (2006).

${ }^{61}$ The latest mortality tables issued by the National Institute of Statistics cover the period 1997-1998.

${ }^{62}$ Diamond and Orszag (2004).

${ }^{63}$ Börsch-Supan (2007).
} 
(4) One of the most problematic elements is including the CR as part of the ABM, because of its implications for the labour market and productivity. As seen in the previous section, regaining solvency without the adjustment load falling exclusively on pensions would mean that the CR would have to be gradually increased, although the onus would not necessarily have to fall on the employer, as it could be shared with the employee or even be deducted from salary increases. The ABMs in Germany and Canada take into account the possibility of increasing the $\mathrm{CR}$ to overcome financial imbalances in the pension system. In Japan there is a stipulated schedule that the $\mathrm{CR}$ is to be raised from 13.58 per cent before September 2004 to 18.3 per cent after September 2017. A very moderate increase in the CR could be included, around 0.1 per cent for each year that the solvency indicator was below the reference value, even though a maximum CR should also be incorporated into the legislation. ${ }^{64}$ The Spanish contributory pension system has an additional problem: there is no specific allocation of the total contributions for common contingencies to each of the contingencies. A specific allocation would first need to be decided that would also clarify the flow of resources to each contingency, and this would make it easier to calculate each contingency and enable an accurate actuarial result to be obtained.

(5) Finally, it would appear to be difficult to include in the mechanism any substantial decrease in the relative value of pensions in payment, although at the same time it would be unfair for all the burden to fall on current contributors and future pensioners. As seen in the section "Automatic balance mechanism", all ABMs include measures that affect current pensioners. The adjustment in the case of pensioners could be for pensions in payment to be revalued below the reference index (real past RPI). An acceptable level could be at a value of between 75 and 90 per cent of the index for each year the solvency indicator was below the reference value. The mechanisms in Japan and Canada include the possibility of freezing pensions in payment in nominal terms. Pensions in Sweden and Germany are also subject to adjustment when the solvency or sustainability indicators require it.

In short, the fundamental elements for designing the mechanism if the pension system remains in the form of $\mathrm{DB}$ could be based on:

- A reduction in the RR of between 0.25 and 0.75 per cent for each year in which the solvency indicator remains below the reference value, even if a minimum RR were legislated in order to guarantee an adequate old-age benefit.

- An increase in the retirement age of between 2 and 3 months a year for each year that the solvency indicator is below its reference indicator, although this measure would not need to be used in the mechanism if in the end the pension system were reformed to become an NDC.

- The adoption of a life expectancy coefficient that would preferably be independent of the system's situation of solvency.

${ }^{64}$ Obviously this measure will not be applied if the pension system were reformed to become an NDC. 
- An increase in the CR of around 0.1 per cent for each year that the solvency indicator is below the reference value, although the burden would not necessarily have to fall on the employer, as it could be shared with the employee or even deducted from salary increases. A maximum CR should also be incorporated into the legislation.

However, any proposal for a specific mechanism would involve carrying out a study in order to adapt it to the characteristics of the Spanish economy, its contributors and pensioners, so as to determine how many of the measures suggested above would need to be included and to what extent each of those measures would need to be applied. This task is a subject for future research.

\section{Concluding comments}

This paper has shown the advisability of applying ABMs to adjust or stabilise a system in order to guide it onto the road to long-term financial stability, to automate the measures to be taken - taking them out of the political arena, avoiding their delay and a lack of time perspective - to ensure the periodic monitoring of sources of pressure on pensions and to build public confidence.

The ABM is a selection of predetermined measures set by law to be applied immediately as required by the solvency indicator in order to re-establish the solvency or financial sustainability of PAYG pension systems through successive application. It also serves to depoliticise the design changes and minimise the electoral use of the PAYG system, adopting measures with a long-term planning horizon to bring about greater intergenerational equity.

ABMs are linked to a pre-existing solvency or sustainability indicator for the system, which implies that they will only be applied in societies that are socially (democratically) advanced and in which politicians voluntarily renounce the exercise of populism in pensions and fully support transparency through the institutionalisation of annual actuarial reports on the solvency or financial sustainability of the system and the application of a stabilising mechanism should the solvency indicator require it.

Spain is still a long way from being able to aspire to a mechanism of this type despite the fact that introducing one would be highly desirable. The main problem preventing its introduction is the absence of an official solvency indicator showing the pension system's true situation of solvency. In this paper we have shown that the absence of an actuarial balance sheet causes a "mirage effect", since the presence of a capital deficit coexisting with a cash surplus minimises the importance of future cash deficits and more especially delays effective measures being taken to restore solvency to the system.

There are not too many options for designing a mechanism in the case of Spain, given that the degree of insolvency is high and there is also a definite problem of structural actuarial imbalance. The mechanism should be of the hard response type, in which pensions are reduced and contributions increased simultaneously along with an obligation to carry out a structural (notional) reform within a defined period of time ( 5 years). The mechanism would need to set a more sustainable, realistic and fair 
actuarial structure for the pension system - 40-45 (years of contributions and full WL), 65-70 (retirement age) and 80-85 (theoretical RR) - which would restore balance by reducing the expected IRR for contributors.

The adoption of these measures is more urgent than may appear because of the foreseeable ageing of the population: the age of the median voter may increase to 56 by 2050, which would increase resistance to the reforms.

Last but not least, it would appear justified to call for the official compilation of an actuarial balance sheet by the office of the chief actuary or similar body such as exists in some countries, which would have to be created in Spain, so as to inform society of the pension system's true situation and the advisability of introducing an ABM to set the system firmly on the road to long-term financial solvency and basically neutralise the effects of ageing, the changes in socioeconomic conditions and the persistent increase in longevity and reduce populist practices. Valdés-Prieto ${ }^{65}$ points out that reluctance to take on reforms is often sustained by efforts to hold back information about the financial status of the pension system.

\section{Acknowledgements}

María del Carmen Boado-Penas and Carlos Vidal-Meliá are grateful for the financial assistance received from the Spanish Ministry of Education and Science (Ministerio de Educación y Ciencia) project SEJ200605051 and from the Valencian Economic Research Institute (Instituto Valenciano de Investigaciones Económicas), selected external research grants 2007. We would also like to thank the Spanish Ministry of Labour and Immigration (Ministerio de Trabajo e Inmigración) for providing the figures enabling us to compile the actuarial balance sheet; Pierre Devolder, Jukka Lassila, Sergio Nisticò, Junichi Sakamoto and Salvador Valdés-Prieto for their invaluable help and comments; Peter Hall for his English support; and two anonymous referees for their useful remarks. Preliminary versions of this paper were presented at the 1st Iberian Congress of Actuaries in Lisbon (Portugal), at the XI Applied Economics Meeting in Salamanca (Spain), at the X Italian-Spanish Congress of Financial and Actuarial Mathematics in Cagliari (Italy) and at the XVI Finance Meeting in Barcelona (Spain). Any errors are entirely due to the authors. The opinions expressed in this paper are the responsibility of the authors and do not reflect the views of the Spanish Ministry of Labour and Immigration or the Swedish Ministry of Health and Social Affairs.

\section{References}

American Academy of Actuaries (AAA) (2002) 'Automatic adjustments to maintain social security's longrange actuarial balance', Issue Brief American Academy of Actuaries, September.

Auerbach, A. and Lee, R. (2006) Notional defined contribution pension systems in a stochastic context: Design and stability, NBER WP-12805.

Besley, T. and Prat, A. (2005) 'Credible pensions', Fiscal Studies 26(1): 119-135.

Boado-Penas, C., Domínguez-Fabián, I. and Vidal-Meliá, C. (2007) 'Notional defined contribution accounts (NDCs): Solvency and risk; application to the case of Spain', International Social Security Review 60(4): $105-127$.

Boado-Penas, C., Valdés-Prieto, S. and Vidal-Meliá, C. (2008) 'An actuarial balance sheet for pay-as-you-go finance: Solvency indicators for Spain and Sweden', Fiscal Studies 29(1): 89-134.

Boeri, T., Börsch-Supan, A. and Tabellini, G. (2001) 'Would you like to shrink the welfare state? The opinions of European citizens', Economic Policy 32: 9-50.

\footnotetext{
${ }^{65}$ Valdés-Prieto (2006a).
} 
Börsch-Supan, A.H. (2006) 'What are NDC systems? What do they bring to reform strategies? in R. Holzmann and E. Palmer (eds) Pension Reform: Issues and Prospects for Notional Defined Contribution (NDC) Schemes, Chapter 3. Washington, DC: World Bank.

Börsch-Supan, A.H. (2007) 'Rational pension reform', The Geneva Papers on Risk and Insurance - Issues and Practice 32(4): 430-446.

Börsch-Supan, A.H. and Wilke, C.B. (2006) 'The German public pension system: How it will become an NDC system look-alike', in R. Holzmann and E. Palmer (eds.) Pension Reform: Issues and Prospects for Notional Defined Contribution (NDC) Schemes, Chapter 22. Washington, DC: World Bank.

Brown, R.L. (2008) 'Designing a social security pension system', International Social Security Review 61(1): 61-79.

Capretta, J. (2006) 'Building automatic solvency into U.S. social security: Insights from Sweden and Germany', Policy Brief \#151, The Brookings Institution, March.

Cremer, H. and Pestieau, P. (2000) 'Reforming our pension system. Is it a demographic, financial or political problem?' European Economic Review 44: 974-983.

Diamond, P. (1994) Insulation of pensions from political risk, NBER WP-4895.

Diamond, P. (2004) 'Social security', American Economic Review 94(1): 1-24.

Diamond, P.A. and Orszag, P.R. (2004) 'A summary of saving social security: A balanced approach', MIT Department of Economics, WP 04-21.

Ferh, H. and Habermann, C. (2006) 'Pension reform and demographic uncertainty: The case of Germany', The Journal of Pension Economics and Finance 5(1): 69-90.

Furman, J. (2007) 'Coping with demographic uncertainty', John Brademas Center for the Study of Congress: Research Brief 2.

Hietaniemi, M. and Ritola, S. (2007) The Finnish Pension System, Eläketurvakeskus, Finland: Finnish Centre of Pensions.

Holzmann, R. (2007) 'Toward a Pan-European pension reform approach: The promises and perspectives of unfunded individual account systems', NFT 1/07: 51-55.

Holzmann, R. and Palmer, E. (2006) Pension Reform: Issues and Prospects for Notional Defined Contribution (NDC) Schemes, Washington, DC: World Bank.

Jimenez-Martin, S., Labeaga-Azcona, J. and Vilaplana, C. (2006) 'Award Errors and Permanent Disability Benefits in Spain', Available at SSRN: http://ssrn.com/abstract $=1002306$.

Knell, M. (2005a) On the design of sustainable and fair PAYG pension systems when cohort sizes change, Oesterreichische Nationalbank, WP-95.

Knell, M. (2005b) Demographic adjustment factors for sustainable PAYG pension systems, Oesterreichische Nationalbank, Economic Studies Division, Mimeo.

Knell, M., Köhler-Töglhofer, W. and Prammer, D. (2006) 'The Austrian pension system - How recent reforms have changed fiscal sustainability and pension benefits', Monetary Policy \& the Economy Q2/06: 69-93.

Lassila, J. and Valkonen, T. (2007a) Putting a Swedish brake on pension benefits, Elinkeinoelämän Tutkimuslaitos - ETLA (The Research Institute of the Finnish Economy).

Lassila, J. and Valkonen, T. (2007b) 'The Finnish pension reform of 2005', The Geneva Papers on Risk and Insurance - Issues and Practice 32(1): 75-94.

Lindbeck, A. and Persson, M. (2003) 'The gains from pension reform', Journal of Economic Literature XLI(March): 74-112.

Lindell, C. (2004) Longevity is increasing - What about the retirement age? Finnish Centre for Pensions, WP-6.

Ono, M. (2007) Applying Swedish “Automatic Balance Mechanism” to Japanese Population, paper presented at 2nd PBSS Colloquium, 21-23 May, Helsinki, Finland.

Palley, T. (2000) 'Life expectancy and social security: Why longevity indexing the payroll tax rate makes good economic sense', Journal of Post Keynesian Economics 22: 507-514.

Penner, R.G. and Steuerle, C.E. (2007) Stabilizing Future Fiscal Policy. It's Time to Pull the Trigger, Washington, DC: The Urban Institute, Research Project.

Queisser, M. and Whitehouse, E. (2006) 'Comparing the pension promises of 30 OECD countries', International Social Security Review 59(3): 49-77.

Robalino, D.A. and Bodor, A. (2008) 'On the financial sustainability of earnings-related pension schemes with 'pay-as-you-go' financing and the role of government-indexed bonds', The Journal of 
Pension Economics and Finance, Published online by Cambridge University Press, 16 November 2007, doi:10.1017/S1474747207003186.

Sakamoto, J. (2005) Japan's pension reform, Social protection discussion paper 0541, The World Bank.

Sakamoto, J. (2008) Roles of the social security pension schemes and the minimum benefit level under the automatic balancing mechanism, Nomura Research Papers No. 125.

Settergren, O. (2001) 'The automatic balance mechanism of the Swedish pension system - A non-technical introduction', Wirtschaftspolitische Blätter 4/2001: 339-349.

Settergren, O. and Mikula, B.D. (2005) 'The rate of return of pay-as-you-go pension systems: A more exact consumption-loan model of interest', The Journal of Pension Economics and Finance 4(2): $115-138$.

The Swedish Pension System. Orange Annual Report 2006 (2007) O. Settergren (ed), Stockholm: Swedish Social Insurance Agency (Försäkringskassan).

Turner, J. (2008) Autopilot: Self-Adjusting Mechanisms for Sustainable Retirement Systems, paper presented at 3rd PBSS Colloquium, 4-7 May, Boston, USA.

Valdés-Prieto, S. (2000) 'The financial stability of notional account pensions', Scandinavian Journal of Economics 102(3): 395-417.

Valdés-Prieto, S. (2006a) 'Market innovations to better allocate generational Risk', in D. David Blitzstein, O. Mitchell and S. Utkus (eds) Restructuring Retirement Risks, Chapter 12. Oxford University Press for the Pension Research Council, Wharton School, University of Pennsylvania.

Valdés-Prieto, S. (2006b) ‘Política fiscal y gasto en pensiones mínimas y asistenciales', Estudios Públicos 103: 43-110.

Vicente, A., Pociello, E. and Varea, J. (2003) 'Análisis dinámico de la invalidez: aplicación a los seguros de riesgo', Actuarios 21: 201-224.

Vidal-Meliá, C. and Domínguez-Fabián, I. (2006) 'The Spanish pension system: Issues of introducing notional defined contribution accounts', in R. Holzmann and E. Palmer (eds) Pension Reform: Issues and Prospects for Notional Defined Contribution (NDC) Schemes, Chapter 23. Washington, DC: World Bank.

Vidal-Meliá, C., Domínguez-Fabián, I. and Devesa-Carpio, J.E. (2006) 'Subjective economic risk to beneficiaries in notional defined contribution accounts (NDC's)', The Journal of Risk and Insurance 73(3): 489-515.

Whitehouse, E. (2006) 'New indicators of 30 OECD countries' pension systems', The Journal of Pension Economics and Finance 5(3): 275-298.

Whitehouse, E. (2007) Pensions Panorama, Washington DC: The World Bank.

\section{Appendix}

\section{Data and assumptions for calculating the actuarial balance sheet and the main variables of the general and self-employed regimes}

Data

Figures for the number of pensioners and amounts by contingency, regime, sex and age were obtained from the Spanish Social Security website and from information supplied by the Office of the Deputy Director of Economics at the National Institute of Social Security (Instituto Nacional de la Seguridad Social).

Information on participants registered as working, by regime and sex, and on registered retirement pensions by age was obtained from the Annual Reports of Employment Statistics and Social Affairs for 2006, 2005, 2004, 2003, 2002 and 2001.

Figures for the total amounts of contributions by regime are shown in the economicfinancial report on Social Security budgets for 2008.

Figures for the average contribution bases, by regime and age, have been estimated based on "Microdata from the Continuous Sample of Working Lives 2005" 
(Microdatos de la Muestra Continua de Vidas Laborales) supplied by the Ministry of Labour and Social Affairs (Ministerio de Trabajo y Asuntos Sociales). For the Social Security general regime, for example, work was carried out using a sample of over 600,000 individuals for each of the years estimated for the balance sheet (2001-2006).

\section{Assumptions}

The mortality tables used are those from the National Institute of Statistics (Instituto Nacional de Estadística) 1998-1999. The permanent disability tables are those drawn up by Vicente et al. $(2003)^{66}$ using data from Spanish Social Security. Although only the retirement contingency is evaluated, it should not be forgotten that current workers might not receive their retirement pension for two possible reasons: death or permanent disability. Therefore, to avoid overvaluing liabilities to contributors, multiple decrement life tables need to be used.

The real technical interest rate applied to discount future pensions and contributions is the IRR of the PAYG system. To be consistent with the estimate of the $C A$ (stationary state with population stability and salaries constant in real terms), this rate has to be 0 per cent. It should be noted that the system's financial position does not depend on the amount of assets and liabilities separately but on the relation between them expressed by the solvency ratio.

In the Spanish Social Security system, the total contributions for common contingencies have no specific allocation to each contingency. The allocation of income from contributions applicable to the retirement contingency is calculated by taking into account the percentage represented by expenditure on pensions, for each contingency, out of the total expenditure for common contingencies. This method ensures that, in a stationary state, there is proportionality between spending and income by contingency, and if there is a deficit or surplus, it will be distributed equally among all the common contingencies.

The expenditure on pensions caused by the supplement to minimum retirement benefits ${ }^{67}$ is considered income from contributions. It is assumed that the pensions drawn by each beneficiary remain constant in real terms, as do the minimum and maximum pensions for each year of reference. Salaries (contribution bases) are kept constant in real terms for each age group, which implies supposing that contributors will obtain wage rises only for increases in age.

It is considered that individuals can retire at age $60,61,62,63,64,66$ and 70 . The probability that they will retire at one of these ages is calculated from pension applications by age for the year of reference. The retirement age for individuals of 62 is considered to be equal to 66 and for those of 67 equal to 70. Law 35/2002 is taken into account for those individuals who retire after age 65 . The pension base is calculated by taking into account the 15 years before retirement age. The first pension to which pensioners will be entitled is equal to 100 per cent of the pension base; with a 7 per cent reduction being applied for each year that retirement is

\footnotetext{
${ }^{66}$ Vicente et al. (2003).

${ }^{67}$ The supplements needed to allow the pension to reach the amount known as the minimum pension.
} 
Table A1 Main data and variables (general and self-employed workers' regimes)

\begin{tabular}{|c|c|c|c|c|c|c|}
\hline General and self-employed & 2001 & 2002 & 2003 & 2004 & 2005 & 2006 \\
\hline Contributors (average), $C \mathrm{~s}$ & $14,271,669$ & $14,735,480$ & $15,205,505$ & $15,728,400$ & $16,423,845$ & $17,180,428$ \\
\hline $\begin{array}{l}\text { Contributions } \\
\text { Millions of euros }\end{array}$ & 39,089 & 41,338 & 44,059 & 46,251 & 49,866 & 54,600 \\
\hline $\begin{array}{l}\text { Real contributions (ret) } \\
\text { Millions of euros } 2006\end{array}$ & 45,618 & 46,521 & 48,469 & 49,351 & 51,063 & 54,600 \\
\hline $\begin{array}{l}\text { Average annual contribution } \\
\text { Euros/year }\end{array}$ & 2,739 & 2,805 & 2,898 & 2,941 & 3,036 & 3,178 \\
\hline $\begin{array}{l}\text { Real average annual contribution } \\
\text { Euros/year } 2006\end{array}$ & 3,196 & 3,157 & 3,188 & 3,138 & 3,109 & 3,178 \\
\hline Retirement contribution rate $(\%)$ & 19.20 & 19.11 & 18.96 & 18.70 & 18.71 & 18.79 \\
\hline Retirement pensioners, $P$ s & $2,974,862$ & $3,021,891$ & $3,069,807$ & $3,117,723$ & $3,194,808$ & $3,270,982$ \\
\hline Years contributed (average) & 32.25 & 32.56 & 32.80 & 33.07 & 32.88 & 32.96 \\
\hline $\begin{array}{l}\text { Average annual pension } \\
\text { Euros/year }\end{array}$ & 9,530 & 9,959 & 10,394 & 10,986 & 11,621 & 12,196 \\
\hline $\begin{array}{l}\text { Average annual pension } \\
\text { Euros/year } 2006\end{array}$ & 11,122 & 11,207 & 11,435 & 11,722 & 11,900 & 12,196 \\
\hline (Contributions/benefits) & 1.379 & 1.374 & 1.381 & 1.350 & 1.343 & 1.369 \\
\hline$C$ s per average annual pension & 3.48 & 3.55 & 3.59 & 3.74 & 3.83 & 3.84 \\
\hline$C \mathrm{~s} / P \mathrm{~s}$ & 4.80 & 4.88 & 4.95 & 5.04 & 5.14 & 5.25 \\
\hline$A r$ (years) & 73.08 & 72.47 & 72.60 & 72.71 & 72.78 & 72.83 \\
\hline$A c$ (years) & 39.58 & 39.71 & 39.91 & 40.12 & 40.24 & 40.30 \\
\hline$T D$ (years) & 33.51 & 32.76 & 32.69 & 32.59 & 32.53 & 32.53 \\
\hline$R$ (years) & 63.87 & 63.81 & 63.66 & 63.48 & 63.78 & 63.60 \\
\hline Pay-out (years) & 9.21 & 8.66 & 8.94 & 9.23 & 9.00 & 9.22 \\
\hline Pay-in (years) & 24.29 & 24.10 & 23.74 & 23.36 & 23.54 & 23.30 \\
\hline $\begin{array}{l}\text { GDP at market price } \\
\text { Millions of euros }\end{array}$ & 680,678 & 729,206 & 782,531 & 840,106 & 905,455 & 976,189 \\
\hline
\end{tabular}

Source: Own based on official figures.

brought forward from age 65. On the other hand, an additional 2 per cent is applied for each year that retirement age is postponed beyond age 65 . The average number of years for which contributions have been made at retirement age is obtained from the aggregated information provided by the economic-financial social security report for each year.

The main data and variables used in the calculations are listed in Table A1. The meaning of the items appearing in the data tables are

- Contributors (average): average annual contributors in employment.

- Contributions: amount allocated from contributions for the retirement contingency.

- Real contributions: amount allocated from contributions for the retirement contingency in real terms (2006 values).

- Average annual contribution: quotient between (average) contributions and contributors.

- Real average annual contribution: quotient between (average) real contributions and contributors.

- Retirement rate per cent: contribution rate as a percentage allocated to the retirement contingency. 
- Retirement pensioners: average annual number of pensioners.

- Average number of years contributed: average number of years paying contributions for pensioners who that year receive retirement pension.

- Average annual pension: annual average pension received by pensioners.

- Real average annual pension: real annual average pension received by pensioners (2006 values).

- (Cont rate/Pens rate): quotient of the income from contributions and spending on pensions for the retirement contingency. It includes in the contributions the total amount needed to finance the minimum pension.

- $C$ s per average annual pension: number of contributors needed to finance the average annual pension every year.

- $C \mathrm{~s} / P \mathrm{~s}$ : ratio between contributors and pensioners.

All the other items that play a part are related and are the basis for calculating the $C A$ in the actuarial balance sheet: $A_{c}$ being the average weighted age for the contributors (weighted by contribution sizes that take into account the age - earnings profile) at the end of year $t, A_{r}$ being the average weighted age for the pensioners (weighted by pension size that takes into account the age-benefits profile) at the end of year $t$ and $R$ the average weighted retirement age. The difference, $\left(A_{r}-A_{c}\right)=T D$, is the average maturity period of one monetary unit (m.u.) in the simplified scenario, which can be disregarded in two sub-periods: contribution period, $p t_{c}$ (pay-in duration), and retirement period, $p t_{r}$ (pay-out duration):

$$
A_{r}-A_{c}=\left(A_{r}-\bar{R}\right)+\left(\bar{R}-A_{c}\right)=p t_{r}+p t_{c} .
$$

The $C A$ is the result of a formula that indicates the size of both assets and liabilities when the pension system is actuarially balanced and funded by pure pay-as-you-go, in a simplified scenario. Therefore, the ratio of assets to liabilities must be one, regardless of the level and sequence of discount rates.

The general expression ${ }^{68}$ of the $C A$ is the product of the average turnover duration of one m.u. in the system for yearly contributions:

$$
C A_{t}=\underbrace{C_{t} \times \underbrace{\left(A_{r}-A_{c}\right)}_{T D}}_{\text {Contribution asset }}=\overbrace{V_{t}}^{\text {Liabilities }}=C_{t} \times\left(p t_{r}+p t_{c}\right),
$$

with $C_{t}$ being the amount of contribution revenue in year $t$.

\section{Main data and variables of the general and self-employed regimes}

See Table A1.

\footnotetext{
${ }^{68}$ See Settergren and Mikula (2005) and Boado-Penas et al. (2008) for its actuarial basis.
} 


\begin{abstract}
About the Authors
Carlos Vidal-Meliá is an Associate Professor of Social Security and Actuarial Science at Valencia University (Spain) and an independent consultant-actuary. He has published articles on public pension reforms, administration charges for the affiliate in capitalisation systems, the demand for annuities, NDCs and the actuarial balance for pay-as-you-go finance in refereed international publications. He holds a $\mathrm{PhD}$ in Economics from the University of Valencia and a degree in Actuarial Sciences from the Complutense University of Madrid.
\end{abstract}

María del Carmen Boado-Penas holds a PhD in Economics (Doctor Europeus) from the University of Valencia and a degree in Actuarial Sciences from the University of the Basque Country. She has also published two articles on public pension systems in prestigious international reviews. She has cooperated on various projects related to pension systems at the Swedish Social Insurance Agency in Stockholm.

Ole Settergren is the head secretary in the government's commission to start a unified Swedish Pension Agency. He was director of the Pensions Department at the Swedish Social Insurance Agency 2004-2008. While insurance expert at the Ministry of Health and Social Affairs (1995-2000), he proposed the automatic balance method of securing the financial stability of the new Swedish pension system. He developed the accounting principles that have been used since 2001 in the annual report of the Swedish Pension System and was its editor from 2001 to 2007. 